\title{
THE PRACTICE OF VIRTUAL DEMOCRACY BY GOVERNMENT PUBLIC RELATIONS ON SOCIAL MEDIA
}

\author{
Akhmad Nur Huda ${ }^{1}$, Effy Zalfiana Rusfian ${ }^{2}$ \\ \{Ahmed.nurhuda@gmail.com ${ }^{1}$, effy_rusf@yahoo.co.id ${ }^{2}$ \} \\ Faculty of Social and Political Science, University of Indonesia ${ }^{1}$, Faculty of Social and Political \\ Science, University of Indonesia ${ }^{2}$
}

\begin{abstract}
Virtual democracy is very important in the era of social media as a means of socializing policies and disseminating information. Government PR takes advantage of virtual democracy to bridge communication between government and citizen. This study aims to evaluate the practice of virtual democracy by government public relations on social media which is associated with the public relations task of assisting civil servants in implementing their institutional agenda and fulfilling democratic responsibilities. The analysis was conducted with a quantitative method using a typology of the government's public relations objectives. The results of the study show that government public relations in utilizing social media has carried out its functions as a democratic obligation in serving the community, especially in conducting media relations. Social media is also used as a tool to convey the government's agenda to the public. Different social media are used differently.
\end{abstract}

Keywords: Virtual democracy, government, public relation, social media

\section{Introduction}

Communication is a basic prerequisite for democracy [1]. That means the communication obligations of government managers include responding to questions from the news media, reporting to voters on agency activities, and generally being responsive to the public [2].

Public Relations is one of many strategies that the government can use to improve policy dialogue with citizens [3]. Public relations can help public administrators do a better job by being better at implementing the agency's central mission and fulfilling the democratic responsibilities inherent on government [2].

The emergence of ICT and social media has interrupted the democratic processes that have guided public decisions making for almost two centuries [4]. The development of ICT gave rise to what is called virtual democracy, where all aspects of democracy occur in the online realm, be it blog, website, email, or social media. The presence of Youtube and other platforms has clearly permitting and legalizing lines of communication that have never been done by the government in serving the community. This is an important aspect of this 
research. At this time, government PR uses social media channels to become a liaison between the community and the government.

Previous research shows various roles of government public relations in communicating with its citizens. Dunan in his study of 3 social media from 3 government institutions shows that social media can increase interactivity between the government and the public [5]. This was als o emphasized by Anggreani when researching social media from 2 city governments. She stated that government social media is effectively used as a means or a door to communicate with the public. [6]. Previous studies have only shown the role of government public relations in communicating with citizens, but no one has specifically addressed the theme of virtual democracy.

Based on data fromthe Indonesian Internet Service Provider As sociation [5], there are 171.17 million internet users in Indonesia or $64.8 \%$ of Indonesia's 264 million population. As many as $93.9 \%$ of u sers are stuck with the internet using mobile phones every day. The use of social media ranks second (18.9\%) after communication via messages $(24.7 \%)$ in terms of the main reas ons for using the internet. Facebook is the mostaccessed social media site at 50.7\%. Instagram ranks second with $17.8 \%$ then followed by Youtube by $15.1 \%$. Twitter occupies the last position of $1.7 \%$. The data shows that Indonesians have a high level of interaction with social media so that it is a potential for government public relations to get closer to its citizens

The Minis try of Trade (MoT), has implemented communication strategies in the digital era through online PR activities. In its online PR activities, MoT uses various social media such as Instagram, Twitter, Facebook and Youtube. MoT's PR uses social media to convey information regarding trade including regulations, tariffs, exports, imports, and standardization. MoT's social media is also us ed to create interactions between government and citizens. Informed citizens are the cornerstones of a democracy, and keeping stakeholders and the public informed has been a cornerstone of public relations for half a century [4]. Without communication between citizens, civil society, and the state in the public sphere, there will be a crisis of legitimacy and authority [6].

This study aims to explain communication patterns of MoT public relations through content analysis of social media accounts with Mordecai Lee (2012) government public relations typology approaches

\section{Theoretical Background}

\subsection{Virtual Democracy}

Democracy is a mode of decision making regarding rules and policies that bind and control people collectively where all members have equal rights in decision making [7]. Democracy is a political regime that holds contested elections [8] where individuals have the power to decide through competitive struggles for popular votes [9].

Democracy involves the responsiveness of governments and leaders who are sustainable towards the concerns and preferences of its citizens [10]. Leaders and citizens are politically equal and also citizens' preferences are weighted without discrimination [10].

Virtual democracy is the expansion of democracy and citizen participation in government with computer-mediated communication (CMC) and new communication technologies [11]. It is an effort to practice democracy without limitation of time, place, and other physical condition [12]. 
Politics begins with the people share their ideas [13]. That is why ICT can help governments and its citizen in creating public policies through a process of debate, clarification and persuasion through communication technology [11].

There are four patterns of information traffic in new media in the political sphere [12]. First is allocution, which is a simultaneous distribution of information fromthe government to the community. Allocution has a one-way nature that eliminates the nature of the active audience in selecting information. This pattern is a general pattern that appears in traditional mass media and the practice of political communication in society. The birth of ICT caused a shift from allocution to consultation. Consultation is the selection of centralized information that refers to papers, books, magazines or other print sources and representatives from the government, both from PR and officials.

Third is regis tration which is a collection of information froma data center. In traditional democracy, registration refers to the printed form of questionnaire entries, voting, archives, and visual observations. Registration is one of the main sources of information for the government and public administration.

The last pattern is a conversation that is an exchange of information carried out by two or more parties. Conversations occur in the form of public meetings or interpersonal exchange of information between residents and representatives. In virtual democracies, exchanges occur in the form of e-mails, teleconferences and online groups.

\subsection{Social Media in Government Public Reletion}

Public relations is the management function that establishes and maintains mutually beneficial relationships between an organization and the public on whomits success or failure depends [14]. According to International Public Relation Association (IPRA), "public relations is a decision-making managementpractice tasked with building relationships and interests between organisations and their publics based on the delivery of information through trusted and ethical communication methods ${ }^{6}$ [15].

Historically, government public relations initially disseminated public information utilizing traditionalmas s media [16]. In the past, governments had to rely almost exclusively on traditional media [17], es pecially newspapers, television and radio, to get information to citizens. Communication goes in one direction, from the government through its public relations to the community.

The emergence of ICT and other communication technologies causes PR to adapt to the new environment. Cyber PR then emerges as a new form of awareness that PR is also required to establish relationships with customers directly through social networks, online communities and blogs [18].

Social media has enormous potential. But many PR practitioners use social media only as a powerful tool for marketing and advertising activities [19]. Whereas socialmedia can also be used for more tangible activities such as relationship building, problem solving, crowd sourcing, design improvement [4]. The interactive aspect, instant capabilities, and pervasive nature of social media are factors that able to transform governance in the field of transparency and interaction $\lceil 20\rceil$.

Government institutions use social media to create democratic participation, new institutional structures, and trans parent governance [20]. Social media can also be used to increase impacts in the public sector, namely to improve policy making, improve public services, and improve knowledge management and cooperation between institutions [21]. For furtherbenefits of socialmedia to the government and the community can be seen in Figure 1. 
However, to achieve those goals, the government must face various challenges in form of policy development, governance, process design, and concepts of democratic engagement [20].

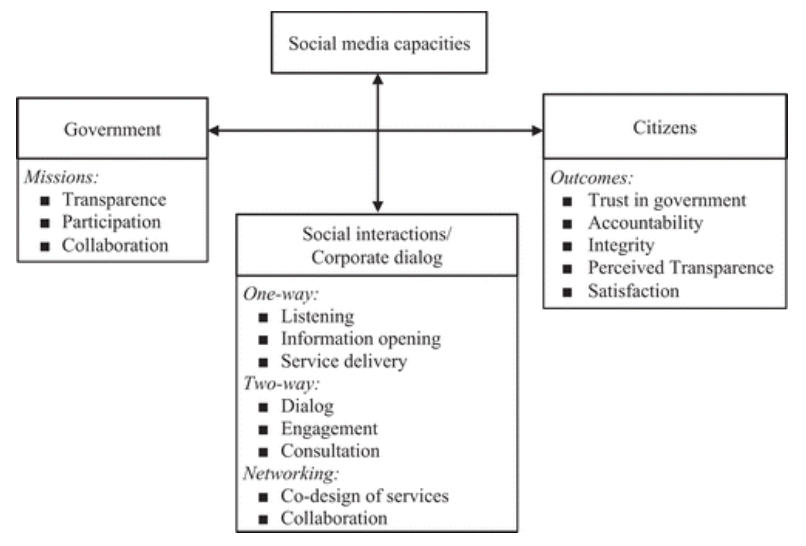

Fig. 1. Relationship between government, social media, and citizens. [22]

There are three levels of social interaction through the use of social media. First is Oneway interaction such as dissemination information and services or for listening and monitoring. Second is two-way interaction includes online dialogue between both government and citizen, submis sion of ideas and content, and consultation with relevant stakeholders. The last level is collaboration between government and citizen in form of joint development, design, and delivery of government services as well as crowdsourcing solutions and innovations [23].

\subsection{Government Public Relation Typology}

Lee in his book The Practice of Government Public Relations (2012) divides government public relations into 3 types of typologies in public relations activities with government. The first typology is Obligatory to Government Employees which is the democratic purpose of government public relations. There are three categories in this typology, which are media relation, public reporting, and responsiveness to the public (as a citizen).

Media relation is an activity to establish relationships / relations with the mass media, journalis ts or the press to establis $h$ cooperation and good relations by an organization. It will affect the news or mes sage in the mas s media itself to maintain a positive impression. Public reporting is the general task of government public relation to convey information to the public about government activities. In general, this activity is a post-activity activity that focuses on the past. Responsiveness to the public (as a citizen) is a a key concept regarding the appropriate role of government in a democratic political system. The government cannot ignore criticism from the community because the community is the stakeholder of the government. In addition, the principle of openness, transparency and freedom of information plays an important role.

The second ty pology is Optional but Useful. It can be called as a pragmatic objectives of government public relations. There are 5 categories within this typology. First, 
Responsiveness to the public (as a cutomer and client) has activity similar to the previous category. The difference is the source of input where in this category looks at input from clients and government customers.

Second, Increase the use of services and products is one of the goal of public relation. PR must be involved in reaching out and informing potential customers and service clients that they might be able to use. Third is Public service campaigns. PR are encouraging behaviors that have broad social agreement and reflect broadly held values. PR can utilize paid or free media coverage to facilitate completing its mis sion while reducing campaign expenses.

The fourth category is Seek voluntary public compliance with laws and regulations. Governments can reduce their regulatory costs by utilizing community relations to encourage community voluntary compliance with new laws, regulations and programs for them to implement. This is a cost effective approach to the implementation phase of the policy process. The last category in this typology is Using the public as an eye and ear agent. Government agencies can encourage citizens to become their eyes and ears, thereby reducing staffing needs.

The last typology is Dangerous but Powerful for Government. It is the Political Purpose of Government Public Relations. There is only one category, which is to Increase Public Support. Lee states that in general, government institutions want autonomy without interference fromother institutions or parties. Good public relations can increase the power of agents and help them grow and develop.

\section{Method}

This study use content analysis as researh method, which aims to describecharacteristics and aspects of a mes sage [24]. This study will analyze four Minis try of Trade social media in the form of Youtube, Facebook, Instagram, and Twitter. Data is taken from the period of January 1 to September 302018. Data will be coded according to the typology of democracy from Mordecai Lee (2012). Then, the data will be interpreted and compared between the four social media.

\section{Result and Discussion}

The Ministry of Trade's Public Relations is one of the bureaus under the General Secretariat of the Minis try of Trade. This unit has the task of carrying out the coordination and implementation of the mass media and publications, re lations between institutions, and public information.

One of the MoT's Public Relations subdivision is the Multimedia Subdivision. This subdivision manages the digital as sets of the Public Relations Bureau, namely Facebook with the name of the Ministry of Trade, Twitter with the name @ kemendag, Youtube with the Ministry of Trade channel, and Instagram with the @ kemendag account.

During January - September 2018, we found 37 number of posts on Youtube, 166 posts on Facebook, 152 posts on Instagram, and 1227 number of tweets conducted by the Ministry of Trade PR. 
Table 1: Media relation activity in MoT social media

\begin{tabular}{|l|c|c|c|c|c|c|c|c|}
\hline \multirow{2}{*}{ Category } & \multicolumn{2}{|c|}{ Youtube } & \multicolumn{2}{c|}{ FB } & \multicolumn{2}{c|}{ IG } & \multicolumn{2}{c|}{ Twitter } \\
\cline { 2 - 10 } & Amount & $\%$ & Amount & $\%$ & Amount & $\%$ & Amount & $\%$ \\
\hline Media relations & 0 & $0 \%$ & 1 & $0,6 \%$ & 1 & $0,66 \%$ & 5 & $0,07 \%$ \\
\hline
\end{tabular}

On the Minis try of Trade's social media, there are no posts regarding media relations on Youtube. This shows that Youtube is not used by the Ministry of Trade's PR to conduct media relations. There is $1(0.6 \%)$ post on Facebook, 1 post $(0.66 \%)$ post on Instagram, and 5 tweets about Media Relations. All three of these social media share the same information, which is about cooperation activities between the Minis try of Trade and Kompasiana. But on Twitter, the Ministry of Trade's PR give more detailed information regarding the activities with the hashtag \#NgobrolPerdagangan.

In the tweet, Trade Minis ter Enggartiasto Lukita chatted with Kompasiana bloggers during an event at the Ministry of Trade's Office. During the event, the Minister of Trade explained that the Ministry of Trade is always on the side of the community, one of which is by always maintaining the availability and stability of prices for basic commodities for the people. The Compassers enthusiastically raise questions to the Minister of Trade regarding trade issues.

In addition, there are also reports of coverage of journalists from various media when covering the news in the Ministry of Trade. There were tweets about reports of coverage visits in several coverage locations with officials at the Ministry of Trade.

The table above shows thatMoT provides a small portion of media relations through social media. This can be detrimental to the Ministry of Trade because public access to mass media is greater than access to media managed by the Ministry of Trade. The government has a dependency on the mass media to distribute various information, es pecially press releases. Government press releases are deemed to have rigid language that does not sell, so it requires journalists to process them. In fact, by doing good media relations, the government also implements good governance practices at the same time [25].

Table 2: Public reporting activity in MoT social media

\begin{tabular}{|c|c|c|c|c|c|c|c|c|}
\hline \multirow{2}{*}{ Category } & \multicolumn{2}{|c|}{ Youtube } & \multicolumn{2}{c|}{ FB } & \multicolumn{2}{c|}{ IG } & \multicolumn{2}{c|}{ Twitter } \\
\cline { 2 - 9 } & Amount & $\%$ & Amount & $\%$ & Amount & $\%$ & Amount & $\%$ \\
\hline Public reporting & 7 & $18,92 \%$ & 106 & $63,86 \%$ & 38 & $25 \%$ & 460 & $37,49 \%$ \\
\hline
\end{tabular}

There are 7 videos (18.92\%) on Youtube, 106 (63.86\%) posts on Facebook, 38 (25\%) Instagram posts, and 460 posts (37.49\%) Twitter. The contents of the four social media are the same, regarding various activity reports in the formof photos, videos, and texts of the Minister and his official's activities.

Public reporting is a report of past government activities to citizens. This category includes thety pology of governmentobligations to citizens. In this typology, the government, in this case the Ministry of Trade, reports that many activities are carried out as accountability to the community as government funders. 
Table 3: Response to the Public as a Citizen activity in MoT social media

\begin{tabular}{|c|c|c|c|c|c|c|c|c|}
\hline \multirow{2}{*}{ Category } & \multicolumn{2}{|c|}{ Youtube } & \multicolumn{2}{|c|}{ FB } & \multicolumn{2}{c|}{ IG } & \multicolumn{2}{c|}{ Twitter } \\
\cline { 2 - 8 } & Amount & $\%$ & Amount & $\%$ & Amount & $\%$ & Amount & $\%$ \\
\hline Responsiveness to the public (as a citizen) & 16 & $43,25 \%$ & 31 & $18,68 \%$ & 28 & $18,42 \%$ & 381 & $31.05 \%$ \\
\hline
\end{tabular}

Found 16 videos $(43.52 \%)$ on Youtube, 31 posts $(18.68 \%)$ on Facebook, 28 posts $(18.42 \%)$ on Instagram, and 381 posts $(31.05 \%)$ Twitter. On Youtube, this category dominates the number of video posts containing the Minister of Trade making various visits and conducting dialogues in various markets in Indonesia. In the video dated June 25, 2018, the Minis ter of Trade monitors the prices of staple goods at Jimbaran Traditional Market and Kuta II Market in Bali, Tues day, May 8, 2018. After dialogue with traders, the Minister of Trade stated that there was no price increase, instead what happened was price reduction. Commodities whose prices are monitored to be stable and even tend to decline include sugar, cooking oil, garlic, shallots and chilies.

The findings show that the Minister of Trade himself responds to the community, even by directly chatting with the community. The Public Relations Ministry of Trade has successfully captured the moment and uploaded it to social media as a form of government responsibility. The government's obligation is to listen to input from the community and use power for the prosperity of the community.

Table 4: Response to the Public as Customers and Clients activity in MoT social media

\begin{tabular}{|l|c|c|c|c|c|c|c|c|}
\hline \multirow{2}{*}{ Category } & \multicolumn{2}{|c|}{ Youtube } & \multicolumn{2}{|c|}{ FB } & \multicolumn{2}{|c|}{ IG } & \multicolumn{2}{c|}{ Twitter } \\
\cline { 2 - 9 } & Amount & $\%$ & Amount & $\%$ & Amount & $\%$ & Amount & $\%$ \\
\hline $\begin{array}{l}\text { Responsiveness to the public (as a cutomer and } \\
\text { client) }\end{array}$ & 10 & $27,03 \%$ & 4 & $2,41 \%$ & 11 & $7,24 \%$ & 181 & $14,75 \%$ \\
\hline
\end{tabular}

This categ ory has a lot of posts on allfour social media. There are 10 posts $(27.03 \%)$ on Youtube, 4 posts $(2.41 \%)$ on Facebook, 11 posts (7.24\%) on Instagram, 181 posts $(14.75 \%)$ on Twitter. This category contains joint activities between the Ministry of Trade and its various clients and customers from various companies and entrepreneurs.

One example is the Minister of Trade, Enggartiasto Lukita accompanied by the Ambassador of South Korea to Jakarta, Kim Chang-beom and the Director General of Foreign Trade, Oke Nurwan, President Director of PT Multi Bintang Indonesia, Michael Chin; officially launched the Prime Export of Bintang Beer to South Korea which took place at the PT Multi Bintang Indonesia Office, Tangerang, Banten, Monday, May 14 2018. The Minister of Trade ensured that the government and related authorities would help to increase the number of exports from Indonesia, especially to South Korea because the two countries agreed to increase bilateral trade and investment.

Apart from the community, the government also has clients in the formof companies and otherins titutions. The government must always be responsive, but in this category, the response taken is optional, in the sense that the government must prioritize its citizens over 
other clients. The findings show that apart from having a good res ponse to the community, the Minis try of Trade also has a good response to other clients.

Table 5: Increasing Utilization of Services and Products activity in MoT social media

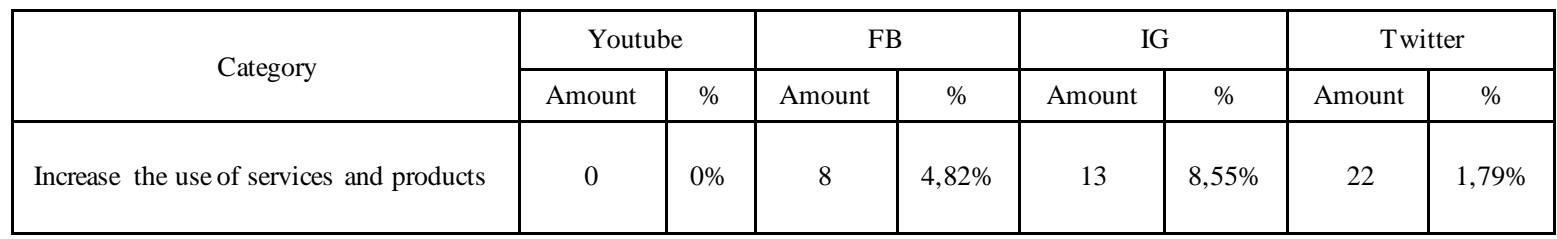

There were no video posts found on Youtube, there are 8 posts $(4.82 \%)$ on Facebook, 13 posts $(8.55 \%)$ on Instagram, and 22 posts $(1.79 \%)$ on Twitter. This category contains photos and texts of Minis try of Trade facilities and services, such as libraries, and the Free Trade Area (FTA) Center, Export Training Center, and Desaigner Dispatch Center (DDC).

This categ ory shows that the Ministry of Trade also uses social media to introduce facilities and products owned by the institution. The delivery of products to the community is very important in supporting the duties and functions of the Ministry in serving the community. Social media can help in disseminating information.

Table 6: Public Education Campaign and Public Services activity in MoT social media

\begin{tabular}{|c|c|c|c|c|c|c|c|c|}
\hline \multirow{2}{*}{ Category } & \multicolumn{2}{|c|}{ Youtube } & \multicolumn{2}{|c|}{ FB } & \multicolumn{2}{|c|}{ IG } & \multicolumn{2}{|c|}{ Twitter } \\
\hline & Amount & $\%$ & Amount & $\%$ & Amount & $\%$ & Amount & $\%$ \\
\hline $\begin{array}{l}\text { Public education and public service } \\
\text { campaigns }\end{array}$ & 4 & $10,81 \%$ & 14 & $8,43 \%$ & 54 & $35,53 \%$ & 148 & $12,06 \%$ \\
\hline
\end{tabular}

In this category, there are 4 posts $(10.81 \%)$ on Youtube, 14 posts $(8.43 \%)$ on Facebook, 54 posts $(35.53 \%)$ on Instagram, and 148 posts $(12.06 \%)$ on Twitter. This category contains videos, images and educational texts for the public, such as videos on Importer Identification Numbers (API), tips on choosing basic needs, and various trade infographics.

Educating the public is one of the functions of government. Educating the public can reduce the complaints that occur. The Ministry of Trade's Ins tagramcontent has the most posts in the public education categ ory. Instagram's educational content uses more informal language so it is closer to the community.

Table 7: Seek out General Volunteering for Compliance with Laws and Regulations activity in MoT social media

\begin{tabular}{|c|c|c|c|c|c|c|c|c|}
\hline \multirow{2}{*}{ Category } & \multicolumn{2}{|c|}{ Youtube } & \multicolumn{2}{|c|}{ FB } & \multicolumn{2}{|c|}{ IG } & \multicolumn{2}{|c|}{ Twitter } \\
\hline & Amount & $\%$ & Amount & $\%$ & Amount & $\%$ & Amount & $\%$ \\
\hline $\begin{array}{l}\text { Seek voluntary public compliance with laws and } \\
\text { regulations }\end{array}$ & 0 & $0 \%$ & 1 & $0,6 \%$ & 5 & $3,29 \%$ & 9 & $0,73 \%$ \\
\hline
\end{tabular}


There were no posts found on Youtube. There was one post $(0.6 \%)$ on Facebook regarding s ocialization of joint regulations between the Minis try of Trade and the Business Competition Supervisory Commis sion (KPPU) to create fair busines s competition through discussions of amendments to Law (UU) No. 5 of 1999 concerning the Prohibition of Monopolistic Practices and Unfair Competition.

More various posts were found in Ins tagram (5 posts / $3.29 \%)$ and 9 pos ts $(0.73 \%)$ on Twitter regarding inspection activities with the Police and Customs. There is also post about Minis try of Trade together with the Minis try of Finance and related ministries / institutions held a press conference regarding the results of the prosecution of illegal cellphones and illegal alcohol containing alcohol (MMEA), as well as the largest destruction of goods resulting fromprosecution at the Customs Office in Jakarta, Thursday (15/2). The success of the biggest catch in the history of Customs and Excise is the result of synergy with the NationalPolice, TNI, Attorney General's Office, ministries / agencies, and other agencies ".

Table 8: Using the Public as Government Eyes and Ears activity in MoT social media

\begin{tabular}{|c|c|c|c|c|c|c|c|c|}
\hline \multirow{2}{*}{ Category } & \multicolumn{2}{|c|}{ Youtube } & \multicolumn{2}{|c|}{ FB } & \multicolumn{3}{|c|}{ IG } & \multicolumn{2}{c|}{ Twitter } & Amount & $\%$ \\
\cline { 2 - 9 } & Amount & $\%$ & Amount & $\%$ & Amount & $\%$ & & $0,16 \%$ \\
\hline Using the public as an eye and ear agent & 0 & $0 \%$ & 1 & $0,6 \%$ & 1 & $0,66 \%$ & 2 \\
\hline
\end{tabular}

There were no posts found on Youtube, 1 post $(0.6 \%)$ on Facebook, 1 post $(0.66 \%)$ on Instagram, and 2 posts $(0.16 \%)$ on Twitter. All three of thes e social media contain the same news which is about the online reporting facility for the public when experiencing a case in trade. [25]

Table 9: Increase public support activity in MoT social media

\begin{tabular}{|c|c|c|c|c|c|c|c|c|}
\hline \multirow{2}{*}{ Category } & \multicolumn{2}{|c|}{ Youtube } & \multicolumn{2}{c|}{ FB } & \multicolumn{2}{c|}{ IG } & \multicolumn{2}{c|}{ Twitter } \\
\cline { 2 - 8 } & Amount & $\%$ & Amount & $\%$ & Amount & $\%$ & Amount & $\%$ \\
\hline Increase public support & 1 & $2,5 \%$ & 0 & $0 \%$ & 1 & $0,66 \%$ & 4 & $0,32 \%$ \\
\hline
\end{tabular}

There were no posts found on YoutubeandFacebook. Socialmedia that contain this typology only on Instagram 1 post $(0,66 \%)$ and Twitter 4 posts $(0,32 \%)$. Both social media have the same story, which is about the pros and cons of rice imports. Instagram only has 1 short post about the need to import special rice. Meanwhile, on Twitter there are four tweets that provide more detailed information with the hashtaf \#Stabilis asiHargaBeras. In its tweet, the Ministry of Trade continues to maintain rice price stability and will not risk food shortages. Therefore, the government needs to import rice because it is to stabilize the price of rice and meet people's needs. Imported rice will enter at the end of January to February to stabilize prices while waiting for the main harvest which will take place from February to March. Bulog will absorb the harvest yields, so prices will not fall. Maysrakat will get affordable prices and farmers will not be disadvantaged. The rice to be imported is a special type of rice. 
The Minister of Trade, Enggartiasto Lukita, together with the President Director of Perum Bulog, Djarot Kusumayakti conducted the release of the rice Market Operation (OP) which took place at the Warehouse of Bulog Divre DKI Jakarta and Banten, Kelapa Gading, Jakarta, Tues day, January 92018 . The release of this rice OP was intended to maintain price stability and availability of basic goods supplies for the people, especially medium rice.

The MoT of the Ministry of Trade ignores the importance of the factor of gaining public support on its social media with the small number of posts in th is category. In fact, this factor provides an important function to find out people's opinions so that they can gain trust in society, especially if there is fluctuation in a policy [27].

\section{Conclusion}

The results of this study indicate that in public relations the Ministry of Trade has carried out its democratic obligations in serving the community on its social media. All category indicators compiled by (Lee, 2012) are all met. The majority of posts are in the mandatory typology section, namely public reporting and responsiveness to the public (as citizens). However, the Ministry of Trade's Public Relations paid little attention to mandatory typologies in the media relations category with very few posts from the four social media.

Another finding obtained is the difference in actions carried out by the Ministry of Trade's public relations on each of its social media. In carrying out virtual democracy activities, the Ministry of Trade's public relations use YouTube more as a responsiveness to the public. While the majority of Facebook and Twitter are used as public reporting. The three social media are used to fulfill democratic oblig ations (mandatory typology). While Instagram majority is used in optional typologies as a means of public education and public service campaigns.

The main limitation of this research is that it only examines the texts contained within the social media. To get more comprehensive results, it is necessary to conduct in-depth interviews with related parties so that it is pos sible to find out the causes for some categories that have small results or other matters that are not revealed from examining the text alone.

For further research, we can recommend to expand the sample by comparing social media from several government agencies. In addition, it can also be linked to other social science theories, such as media richness or leadership pattern from selected institution.

\section{References}

[1] S. A. Young, Ed., Government communication in Australia. Cambridge [England] ; New York: Cambridge University Press, 2007.

[2] M. Lee, G. Neeley, and K. B. Stewart, Eds., The practice of government public relations. Boca Raton: CRC Press, 2012.

[3] A. E. Hopkins, "Government Public Relations: Public Diplomacy or Propaganda?," Inquiries Journal, vol. 7, no. 03, 2015.

[4] M. L. Kent, "Using social media dialogically: Public relations role in reviving democracy," Public Relations Review, vol. 39, no. 4, pp. 337-345, Nov. 2013, doi: 10.1016/j.pubrev.2013.07.024. [5] AP JII, "Penetrasi dan Profil Perilaku Pengguna Internet Indonesia," Asosiasi Penyelenggara Jasa Internet Indonesia., 2018. 
[6] M. Castells, "The New Public Sphere: Global Civil Society, Communication Networks, and Global Governance," The ANNALS of the American Academy of Political and Social Science, vol. 616, no. 1, pp. 78-93, Mar. 2008, doi: 10.1177/0002716207311877.

[7] D. Beetham, "Liberal Democracy and the Limits of Democratization," Political Studies, vol. 40, no. 1_suppl, pp. 40-53, Aug. 1992, doi: 10.1111/j.1467-9248.1992.tb01811.x.

[8] A. Przeworski, Ed., Democracy and development: political institutions and well-being in the world, 1950-1990. Cambridge: Cambridge University Press, 2000.

[9] J. A. Schumpeter and R. Swedberg, Capitalism, socialism and democracy, Transferred to digital print. London: Routledge, 2005.

[10] R. A. Dahl, Polyarchy: participation and opposition, 26. print. New Haven: Yale Univ. Press, 1998.

[11] K. L. Hacker and M. A. Todino, "Virtual Democracy at the Clinton White House: An Experiment in Electronic Democratisation," Javnost - The Public, vol. 3, no. 1, pp. 71-86, Jan. 1996, doi: 10.1080/13183222.1996.11008616.

[12] K. L. Hacker and J. van Dijk, Digital democracy issues of theory and practice. London: SAGE, 2000.

[13] S. London, Electronic Democracy: A Literature Survey. A Paper Prepared for the Kettering Foundation (March 1994). 1994

[14] S. M. Cutlip, A. H. Center, and G. M. Broom, Effective Public Relations. Pearson Custom Publishing, 2000.

[15] IPRA, "pr-definition.” https://www.ipra.org/member-services/pr-definition/.

[16] M. Graham and E. Avery, "Government public relations and social media: An analysis of the perceptions and trends of social media use at the local government level," Public Relations Journal, vol. 7, no. 4, pp. 1-21, 2013.

[17] B. E. Dixon, “TOW ARDS E-GOVERNMENT 2.0: AN," Public Administration, vol. 15, no. 2, p. 37.

[18] B. Solis and D. K. Breakenridge, Putting the public back in public relations: How social media is reinventing the aging business of PR. Ft Press, 2009.

[19] M. Taylor and M. L. Kent, "Anticipatory socialization in the use of social media in public relations: A content analysis of PRSA's Public Relations T actics," Public Relations Review, vol. 36, no. 3, pp. 207-214, Sep. 2010, doi: 10.1016/j.pubrev.2010.04.012.

[20] J. C. Bertot, P. T. Jaeger, S. Munson, and T. Glaisyer, "Social Media Technology and Government Transparency," Computer, vol. 43, no. 11, pp. 53-59, Nov. 2010, doi: 10.1109/MC.2010.325.

[21] E. Bonsón, L. Torres, S. Royo, and F. Flores, "Local e-government 2.0: Social media and corporate transparency in municipalities," Government Information Quarterly, vol. 29, no. 2, pp. 123-132, Apr. 2012, doi: 10.1016/j.giq.2011.10.001.

[22] I. Mergel, "A framework for interpreting social media interactions in the public sector," Government Information Quarterly, vol. 30, no. 4, pp. 327-334, Oct. 2013, doi: 10.1016/j.giq.2013.05.015

[23] B. Lu, S. Zhang, and W. Fan, "Social Representations of Social Media Use in Government: An Analysis of Chinese Government Microblogging From Citizens' Perspective," Social Science Computer Review, vol. 34, no. 4, pp. 416-436, Aug. 2016, doi: 10.1177/0894439315595222.

[24] Eriyanto, Analisis isi: pengantar metodologi untuk penelitian ilmu komunikasi dan ilmu-ilmu sosial lainnya. Jakarta, Indonesia: Kencana, 2011.

[25] C. Soon and Y. D. Soh, "Engagement@web 2.0 between the government and citizens in Singapore: dialogic communication on Facebook?," Asian Journal of Communication, vol. 24, no. 1, pp. 42-59, Jan. 2014, doi: 10.1080/01292986.2013.851722. 